\title{
Polymerase chain reaction amplification of the RuBisCo small subunit genes and their novel application to plant tissue identification
}

\author{
J. M. APPLEBY†‡, G. NELSON†, M. J. McPHERSON $¥$ \& P. F. HAMLYN*† \\ $\dagger B T T G$, Shirley House, Didsbury, Manchester M20 2RB and $\ddagger$ Centre for Plant Biochemistry and Biotechnology, \\ University of Leeds, Leeds LS2 9JT, U.K.
}

\begin{abstract}
Degenerate polymerase chain reaction (PCR) primers and specific PCR conditions have been developed for the selective amplification of a polymorphic region of ribulose-1,5-bisphosphate carboxylase ( $\mathrm{RuBisCo}$ ) small subunit (ssu) genes. Reliable amplification has been achieved for genes from more than 20 plant species from a variety of taxonomic groups. Analysis of Nicotiana species provides strong evidence that the test loci are polymorphic at the interspecies level but show little polymorphic variation at the intraspecies level. This specific multilocus PCR approach provides a powerful counterpart to random amplification of polymorphic DNA (RAPD) and restriction fragment length polymorphism (RFLP) analysis for the identification of plant tissues.
\end{abstract}

Keywords: plant identification, ribulose-1,5-bisphosphate carboxylase, RuBisCo.

\section{Introduction}

Genetic methods for tissue identification and typing have increasingly been applied since the development of powerful genetic fingerprinting techniques (Jeffreys et al., 1985). There is now widespread legal acceptance of DNA evidence provided by a wide range of techniques developed for genetic profiling. Indeed, many are available as commercial and public services (Ferrie et al., 1992). However, despite the range of DNA identification techniques, most are developed to solve a particular problem and are limited in their application, reflecting different strengths and weaknesses. It is therefore desirable that new methods be developed to extend the utility of genetic profiling.

Many genetic profiling tests rely largely on the powerful selectivity of PCR to provide DNA evidence in criminal, paternity or immigration cases and in the protection of rare birds (Verheyen et al., 1995). Random amplification of polymorphic DNA (RAPD) (Welsh \& McClelland, 1990; Williams et al.

Correspondence: P. F. Hamlyn, BTT6, Shirley House, Didsbury, Manchester, M20 2RB, U.K. E-mail: pfhamlyn@bttg.co.uk
1990) amplifies random regions of the target DNA using short arbitrary sequence oligonucleotides. Several workers have developed plant identification systems using this type of methodology ( $\mathrm{Hu} \&$ Quiros, 1991; Böhm et al., 1993; Yang \& Quiros, 1993). Numerous sets of DNA probes, which hybridize to the chosen target species or strain, have been reported along with PCR conditions to facilitate detection of species-specific target loci. These techniques are increasingly being applied to the area of animal and plant tissue identification to aid in the enforcement of environmental protection laws and to check the validity of commercial product labelling (Blackett \& Keim, 1992; Hamlyn et al. , 1992; Nelson et al., 1992; Forrest \& Carrniege, 1994).

The central dogma of most genetic profiling techniques consists in selecting a target locus that is informative for the population to be identified, followed by the development of an assay that will yield information about that locus. By carefully choosing a locus that is informative for all the samples that might be encountered, a single test method can be made applicable to a wide range of species. Eukaryotic genes often comprise noncoding introns that are selectively spliced from the gene 
transcript before translation and exons that represent coding regions that are translated into the gene product. Most of the nucleotide sequence of introns is irrelevant; th' $1 \mathrm{~s}$, accumulation of mutations as a result of repli ation errors is selectively neutral (Futuyma, 1986), meaning that introns will exhibit a higher mutation rate than associated exons of the gene. This differential mutation rate has the consequence that, for a given gene, two species with highly conserved exon sequences may differ quite markedly in the sequences of the introns. Introns therefore represent good targets for detecting polymorphic variation. In order to provide a rapid PCR-based identification system for plant species, an ideal target locus would be specific to plants and would have highly conserved sequences that function as universal targets for PCR primers to amplify a region spanning one or more polymorphic introns (Fig. 1).

A reliable PCR test, based on detection of size polymorphisms in the RuBisCo small subunit (SSU) encoding genes introns, with robust amplification conditions and rapid gel analysis, is described and its suitability for species identification of plants is demonstrated.

\section{Materials and methods}

\section{Plant materials}

The following species of Nicotiana were obtained from L'Institute du Tabac Bergerac, France. $N$. rustica var. Asiatica; N. rustica var. Brasilia; N. rustica var. Kapa; N. rustica var. Limonka; N. rustica var. Ovata; $N$. rustica var. Pumila g; $N$. rustica var. Souffi Cap Bon; N. rustica var. Souffi Gabès; $N$. rustica var. Souffi Sétif; $N$. rustica var. Texana F; $N$. paniculata L.; N. knightiana Goodsp.; N. raimondii Macbr.; N. cordifolia Phil.; $N$. solanifolia Walp.; $N$. glauca Grah.; N. tabacum L.; N. trigonophylla Dun.; $N$. repanda Willd.; N. acuminata Grah.; $N$. nudicaulis Wats.; $N$. suaveolens Lehm. Several species of Eucalyptus were kindly donated by Advanced Technologies (Cambridge) (Cambridge Science Park, U.K.). Other samples of fresh and processed tissues were purchased from a local supermarket.

\section{Extraction of genomic DNA}

No single DNA extraction procedure provided pure DNA from all tissues examined. The technique developed by Doyle \& Doyle (1991) was found to

Schematic representation of a RuBisCo small subunit gene.

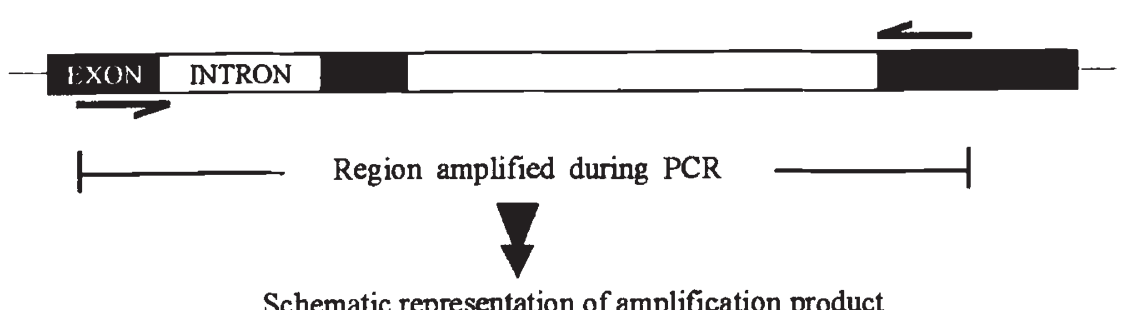

Schematic representation of amplification product

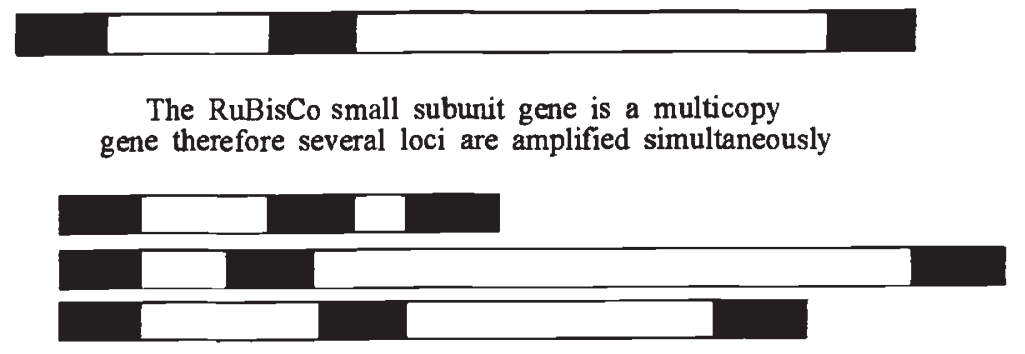

PCR amplification from the polymorphic region of the gene produces several fragments unique to the species tested.

The banding pattern produced after separation of amplification products forms the basis of the genetic profile.

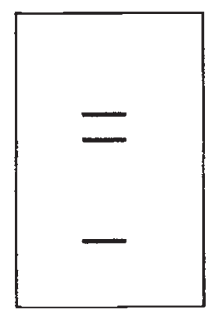

Fig. 1 Schematic illustration of the RuBisCo SSU gene and PCR amplification products. The RuBisCo SSU gene is shown with two introns (white boxes). Most species have several copies of the gene that contain a variable number of introns that can differ in both length and base composition. By using the conserved coding exons (black boxes) as targets for PCR primers it is possible to amplify a DNA fragment that spans the polymorphic introns of the gene. Several amplification products are produced, one for each copy of the gene. When these fragments are separated by gel electrophoresis a unique speciesspecific pattern is produced. 
yield high concentrations of PCR amplifiable DNA from most plant sources. However, for difficult tissues containing high concentrations of phenolic compounds and/or starch this extraction protocol was combined with a further DNA purification step using the silica-based protocol developed by Höss \& Pääbo (1993).

\section{Sequence alignments}

RuBisCo ssu gene sequences were extracted from the EMBL database and analysed using screen orientated multiple alignment procedure (SOMAP) software (Parry-Smith \& Attwood, 1991). A sequence alignment of $N$. sylvestris, $N$. plumbaginifolia, N. tabacum; pine (Pinus sylvestris); pea (Pisum sativum); maize (Zea mays); clover (Trifolium spp.); pear (Pyrus communis) and larch (Larix spp.) was used to locate conserved sequence regions and design PCR primers (Fig. 2).

\section{Oligonucleotide synthesis}

Oligonucleotides were synthesized on an Applied Biosystems 392 DNA synthesis instrument (Perkin Elmer). Following cleavage from the solid support and deprotection no further purification was neces- sary and oligonucleotides were stored in 80 per cent ammonia at $20^{\circ} \mathrm{C}$.

\section{PCR conditions}

Reactions were performed in PCR buffer $(10 \mathrm{~mm}$ Tris $\mathrm{pH} 8.0,0.01$ per cent gelatin, 0.1 per cent Triton X-100, $80 \mathrm{~mm} \mathrm{KCl} ; 3.5 \mathrm{~mm} \mathrm{MgCl}_{2}$ ) containing 35 pм of each primer, $250 \mu \mathrm{M}$ of each dNTP (Pharmacia Ultra pure), 20-100 ng of target DNA, 5 units of Taq DNA polymerase (Boehringer Mannheim). Reaction volumes were made up to 25 $\mu \mathbf{L}$ [HPLC-grade water (Sigma) and overlaid with one drop of mineral oil (Sigma)]. Amplification of the RuBisCo genes was achieved by an initial denaturation step at $94^{\circ} \mathrm{C}$ for $3 \mathrm{~min}$ followed by addition of the polymerase and 35 cycles of $94^{\circ} \mathrm{C}, 20 \mathrm{~s}$; $63.5^{\circ} \mathrm{C}, 20 \mathrm{~s} ; 72^{\circ} \mathrm{C}, 60 \mathrm{~s}$, with a final extension step of 3 min at $72^{\circ} \mathrm{C}$ using a Hybaid Omnigene Thermal Cycler with simulated tube control (calibration factor 150).

\section{PCR analysis}

Aliquots $(3-10 \mu \mathrm{L})$ of the PCR products were fractionated through 2 per cent agarose 1:1 Sigma \& Nusieve (3:1 agarose; FMC) for $2 \mathrm{~h}$ at $7 . \mathrm{V} / \mathrm{cm}$ in Tris-Borate (TBE) buffer and stained with ethidium
Fig. 2 Schematic illustration of the RuBisCo SSU gene and primer sequence alignment. The RuBisCo SSU gene is represented here showing the polymorphic introns (white) and the more conserved, coding exons (black). Highly conserved regions of the gene were chosen for the design of the PCR primers RGI and RGIII.
PCR PRIMER RG I

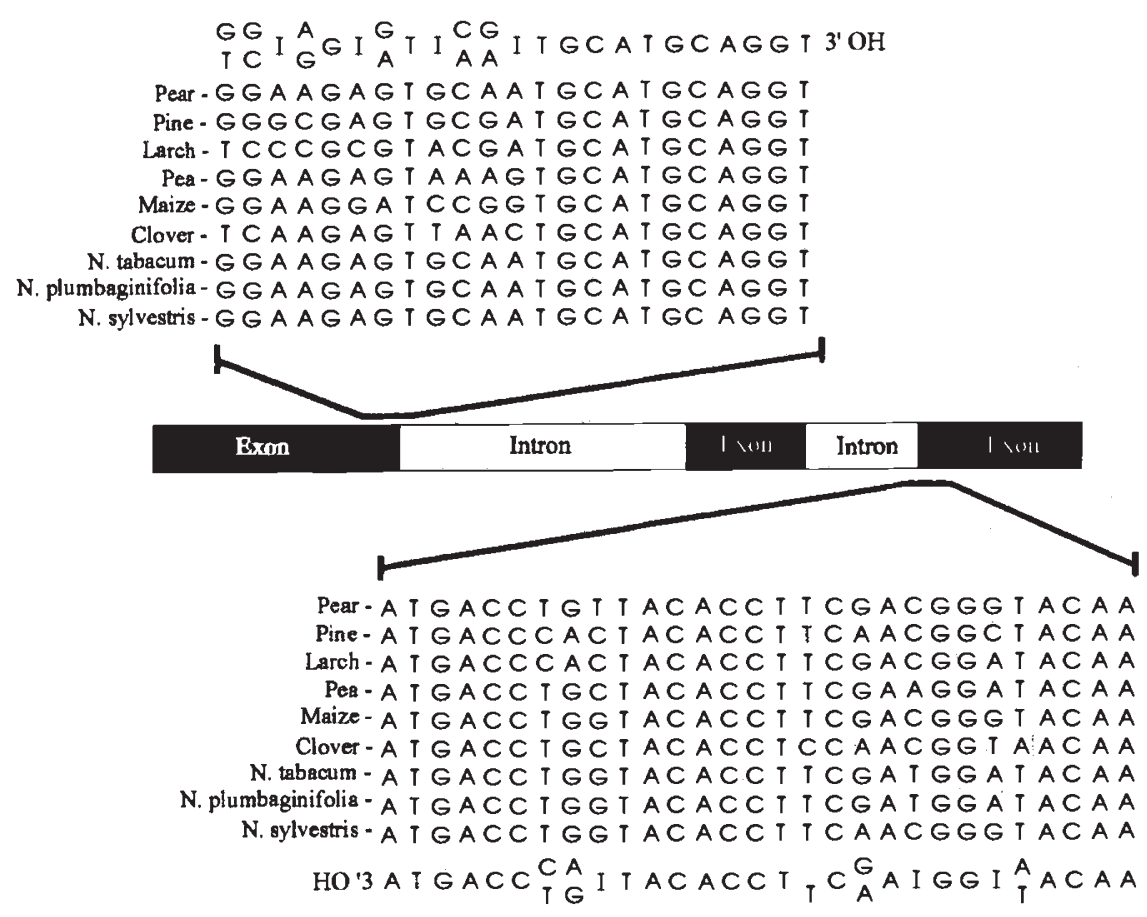

PCR PRIMER RG II

(C) The Genetical Society of Great Britain, Heredity, 79, 557-563. 
bromide as described by Maniatis et al. (1982). DNA gels were photographed using an Olympus OM4 Ti with Ilford XP2400 film. DNA fragment sizes were determined by comparison to $\lambda$ HindIII digest and Pharmacia $100 \mathrm{bp}$ ladder size markers. DNA fragments were isolated from the PCR by direct ligation using PCR, TA cloning kit (Invitrogen). DNA from recombinant plasmids was prepared for sequencing using the Wizard Miniprep Kit (Promega). Sequencing reactions were conducted using the purified plasmid as template at Kings College School of Medicine, London, on an automated ABI 373 A sequencer (Perkin Elmer).

\section{Hybridization}

PCR products were randomly labelled using $\left[\alpha-{ }^{32} \mathrm{P}\right] \mathrm{dCTP}$ and the mega prime kit (Amersham). Southern analysis was carried out as described by Maniatis et al. (1982). Oligonucleotide probes were end-labelled using $\left[\gamma^{32} \mathrm{P}\right] \mathrm{dATP}$ and a Boehringer Mannheim end-labelling kit. Radiolabelled probes were separated from unincorporated nucleotides using Pharmacia G50 columns.

\section{Simulated degradation of genomic DNA}

Freshly extracted Nicotiana tabacum genomic DNA was exposed to high-frequency sonic waves using a heat systems ultrasonic processor coupled to a $20-\mathrm{kHz}$ ultrasonic convertor. The ultrasonic probe was immersed in ice water and the tube containing the DNA held adjacent to the probe in the path of the sonic output. The tube was briefly vortexed and centrifuged before removal of any DNA.

\section{Results and discussion}

RuBisCo is a very large protein with 16 subunits, eight small subunits $\left(14000 M_{\mathrm{r}}\right)$ and eight large subunits $\left(55000 M_{\mathrm{f}}\right)$, which encode the active site. The enzyme, which is located on the stromal surface of the thylakoid membrane, catalyses the conversion of ribulose-1,5-bisphosphate to 3-phosphoglycerate. RuBisCo can also act as an oxygenase, catalysing the conversion of ribulose-1,5-bisphosphate to 3-phosphoglycerate and phosphoglycolate. The large subunit encoding gene is located in the chloroplast genome whereas the multicopy ssu encoding genes are located on different chromosomes throughout the plant genome (Dean et al., 1989). The structure of the ssu genes has certain conserved features, including a leader peptide that, although poly- morphic between even closely related species, has a highly conserved exon region near the junction of the first intron. A second conserved region lies within the final exon of the gene approximately 170 $\mathrm{bp}$ of coding sequence downstream of the first conserved site. These characteristics make the RuBisCo ssu genes a suitable target to allow amplification of several polymorphic introns (Fig. 2).

As different copies of the RuBisCo ssu genes reside at several chromosomal locations, which vary between most species, PCR amplification using this system generates a number of amplification products that can be used to differentiate between species. Amplification from 13 species of Nicotiana (Fig. 3) demonstrates that the RuBisCo ssu genes contain sufficient sequence variation to distinguish between closely related plant species. By comparing the band pattern, including band number, sizes and relative intensities, with the pattern produced from a reference sample it is possible to identify unknown Nicotiana samples. Gene structure and sequence data for Nicotiana species (Dean et al., 1989) allow prediction that PCR amplification would produce two distinct subgroups of amplification products. Larger amplification products, with a size in excess of $700 \mathrm{bp}$, represent gene fragments containing three introns, whereas smaller amplification products, with a size of less than $600 \mathrm{bp}$, contain only two introns. To investigate the extent of varietal differences, the RuBisCo ssu genes profile of 10 varieties of $N$. rustica were analysed (Fig. 4). Some polymorphism exists, with $N$. rustica var. Texana, var. Brazilia and var. Asiatica apparently possessing an additional copy of the gene, which produces an amplification product with a molecular size of approximately $880 \mathrm{bp}$. The variation shown at the test loci demonstrates that PCR amplification of the RuBisCo ssu genes intron could be used to provide a form of identification beyond the species level to the variety level within $N$. rustica. However, the level of polymorphism in any species of interest should be determined in advance of routine testing as four species of Eucalyptus have shown lower levels of polymorphism than Nicotiana (results not shown).

The amplification products for the $N$. rustica varieties (Fig. 4) were digested individually with the fourbase cutting enzymes $R s a \mathrm{I}$ and $A l u \mathrm{I}$. The bands generated for the 10 varieties were very similar (results not shown), demonstrating that there is little sequence variation within the amplification products. Hybridization studies to investigate the use of the amplification products as species-specific probes also showed that there is a high degree of sequence homology between closely related species. The 
Fig. 3 The genetic profile of 13 species of Nicotiana using the RuBisCo ssu gene intron profiling technique. Lanes 1 and 16, size marker (Pharmacia 100-bp ladder); lane $2, N$. paniculata; lane $3, N$. glauca; lane 4, N. langsdorfii; lane 5, $N$. sanderae; lane $6, N$. sylvestris; lane 7, N. tabacum; lane 8, N. repanda; lane $9, N$. accuminata; lane $10, N$. nudicaulis; lane $11, N$. suaveolens; lane 12, N. trigonophylla; lane 13, N. rustica; lane $14, N$. solanifolia; lane 15 , no template control.

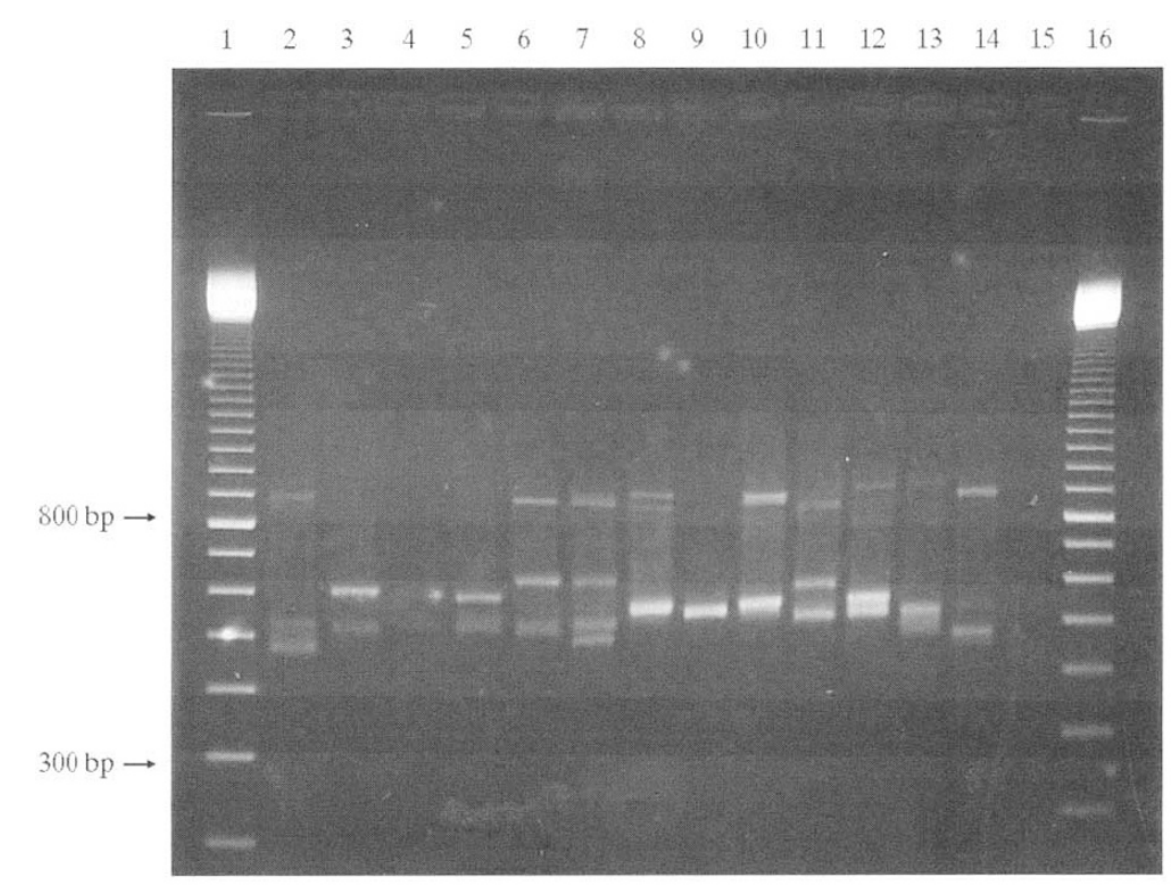

largest amplification product of $N$. glauca (605 bp) was labelled and hybridized to amplification products from other Nicotiana species. Although the probe did not hybridize to bands for most other

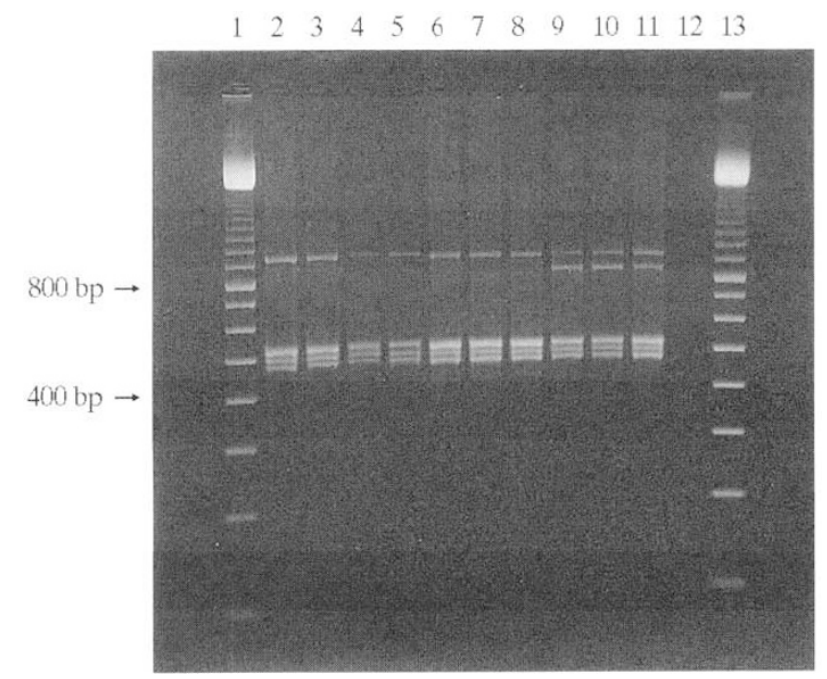

Fig. 4 The genetic profile for 10 varieties of Nicotiana rustica. Lanes 1 and 13, size marker (Pharmacia 100-bp ladder); lane 2, N. rustica var. Souffi Sétif; lane 3, $N$. rustica var. Souffi Gabès; lane $4, N$. rustica var. Pumila g; lane 5, N. rustica var. Limonka; lane 6, N. rustica var. Kapa; lane 7, $N$. rustica var. Souffi Cap Bon; lane 8, $N$. rustica var. Ovata; lane 9, N. rustica var. Texana F; lane $10, N$. rustica var. Brasilia; lane 11, N. rustica var. Asiatica; lane 12 , no template control. species (the probe is largely composed of intron sequences), it did hybridize to $N$. langsdorfii and $N$. sanderae even under stringent wash conditions; these two species appear to be closely related to $N$. glauca. The relatively conserved nature of the RuBisCo ssu genes introns, which hybridize to closely related species and show only limited intraspecies variation, suggests that individuals of a given species are unlikely to show detectable size polymorphisms.

The PCR conditions have been applied to a wide range of different species (Fig. 5); the amplification patterns produced were repeatable and could be used to identify the original DNA sample by comparison of the band pattern with a reference sample. Three amplification products from $N$. sylvestris, one from each band at sizes $850 \mathrm{bp}, 600 \mathrm{bp}$ and $500 \mathrm{bp}$, have been sequenced and all have regions of very high homology to the second exon of the RuBisCo ssu genes. In addition, five further PCR amplification products from Eucalyptus have been sequenced and again all have regions of high homology to the RuBisCo ssu genes.

The test was designed to identify plant material from both fresh and commercially processed tissues. DNA extraction from commercially processed plant tissues has shown that any residual nucleic acid is often highly degraded. In an effort to simulate commercial processing in a controlled manner, high molecular weight DNA, isolated from fresh tissue, was sonicated for varying lengths of time to produce a range of DNA samples with decreasing average 


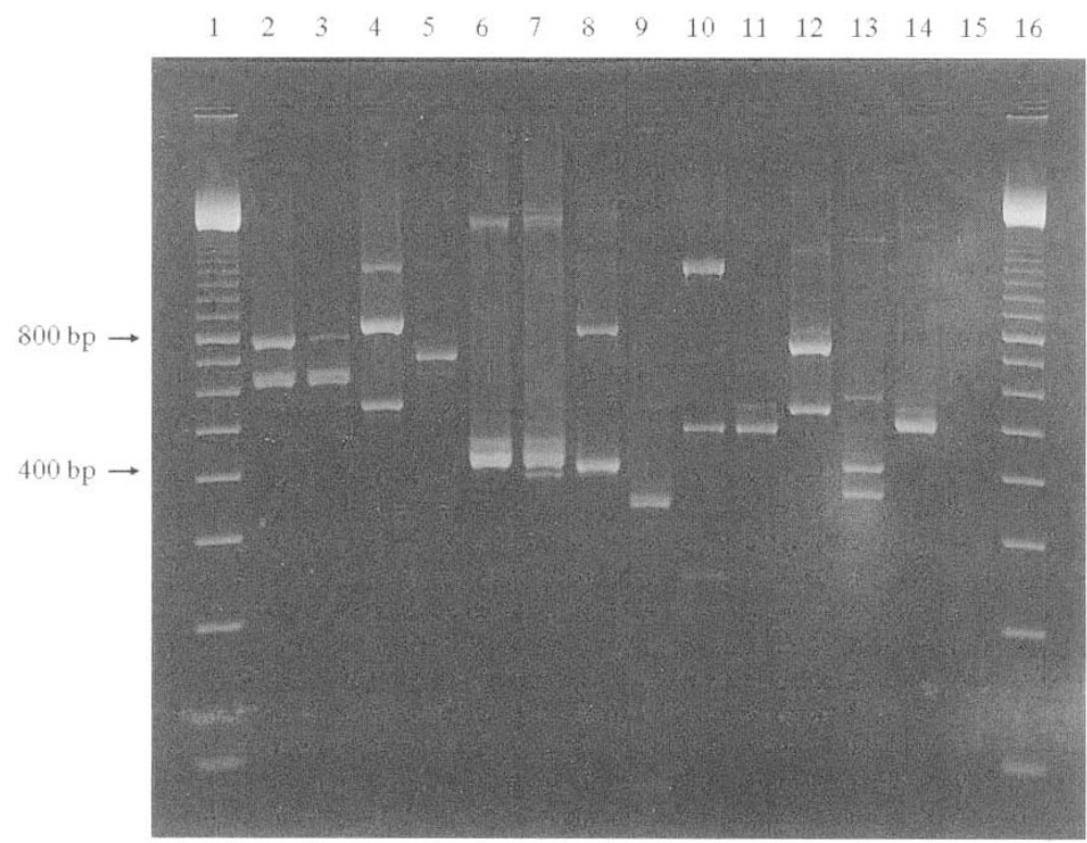

Fig. 5 The genetic profile for 13 species from different taxonomic groups. Lanes 1 and 16, size marker (Pharmacia 100-bp ladder); lane 2, Eucalyptus urophylla; lane 3, Eucalyptus nitens; lane 4, walnut (Juglans sp.); lane 5, turkey oak (Quercus cerris); lane 6, tomato (Lycopersicon sp.); lane 7, potato (Solanum tuberosum); lane 8, pea (Pisum sativum); lane 9, rice (Oryza sativa); lane 10, cacao (Theobroma cacao); lane 11, Arabidopsis sp.; lane 12, soybean; lane 13, maize (Zea mays); lane 14, swede (Brassica sp.); lane 15, no template control. fragment size (Fig. 6a). When tested with the standard reaction conditions, an identical amplification profile is produced as for fresh tissue (Fig. 6b), suggesting that this analysis is applicable to the identification of commercially processed plant material or other samples from which only poorquality DNA is available. To test this hypothesis, DNA was isolated from several brands of cigarettes and cigars and tested using the standard PCR reaction conditions. All samples gave the genetic profile of $N$. tabacum despite the very poor condition of the DNA, which was highly degraded. The PCR conditions have also been tested with variable template concentrations and found to be unaffected by 10 -fold concentration differences. DNA has also been amplified from fully processed white rice.
The PCR conditions outlined in this study are capable of reproducibly amplifying a polymorphic section of the RuBisCo ssu genes from over 20 different species. It has been demonstrated that the intron length polymorphisms that occur at these loci are generally sufficient to allow differentiation between any two different species following gel separation of the PCR products. Although some genetic variation exists in the introns of the RuBisCo ssu genes within a species, as shown by the polymorphisms between $N$. rustica varieties, this could be beneficial to any studies in which the level of polymorphism had already been determined and intravariety discrimination was required. As the target loci are effectively only present in the plant genome, problems of spurious amplification caused
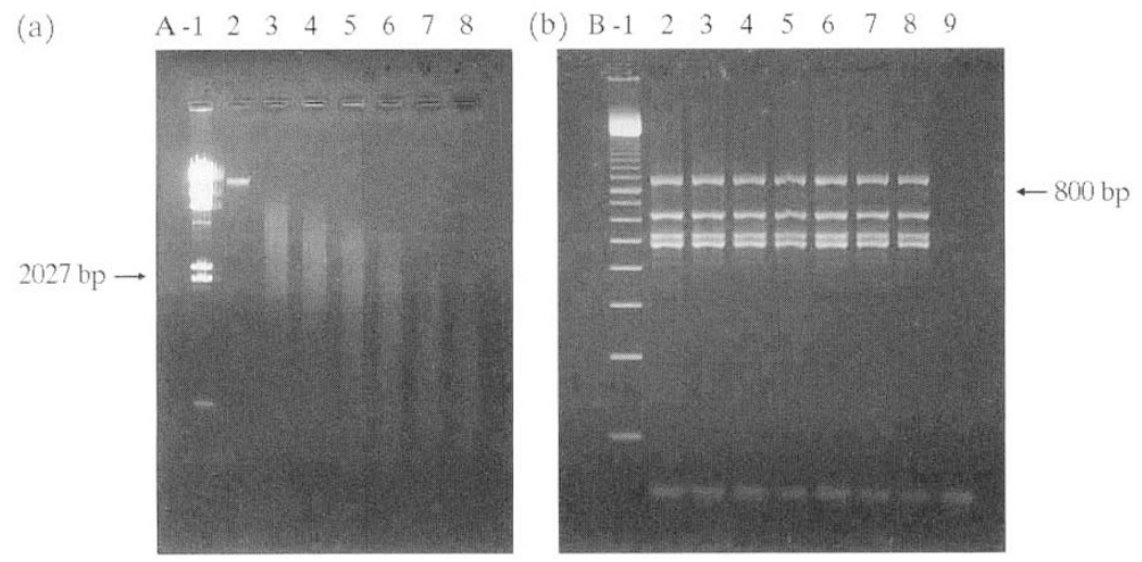

Fig. 6 Genetic profile analysis of sonicated genomic DNA. (a) Simulated degradation of Nicotiana tabacum DNA using sonication. Lane 1 , size marker $\lambda$ HindIII digest (23130, 9416, 6557, 4361, 2322, 2027, $564,125 \mathrm{bp})$; lane 2, untreated genomic DNA; lane $3,30 \mathrm{~s}$; lane 4, 60 s; lane 5, $90 \mathrm{~s}$; lane $6,120 \mathrm{~s}$; lane 7 , $150 \mathrm{~s}$; lane $8,180 \mathrm{~s}$. (b) PCR of sheared DNA from (a) using standard reaction conditions. Lane 1 , size marker, 100-bp ladder (Pharmacia); lanes 2-8, amplification of sheared DNA of corresponding lane in (a); lane 9, no template control.

(c) The Genetical Society of Great Britain, Heredity, 79, 557-563. 
by micro-organisms or human contamination of the sample are significantly decreased while still allowing the detection of contaminating plant matter in adulterated samples. Specific amplification of this nature therefore partially avoids one of the fundamental drawbacks associated with PCR-based analytical techniques.

Kocher et al. (1989) developed a set of primers suitable for amplifying a section of the cytochrome $B$ gene. Many studies have used these reaction conditions to amplify the gene from many members of the animal kingdom, and have used the information gained from subsequent analysis of the amplification product in phylogenetic studies. Successful amplification of the RuBisCo gene may provide a useful additional tool for this form of analysis in the plant kingdom.

It is hoped that further advances in DNA extraction techniques will allow DNA recovery from timber. Provisional results achieved with DNA recovered from pine wood strongly suggest that PCR analysis of the RuBisCo ssu genes from timber could form the basis of a rapid and universal timber identification system.

\section{Acknowledgements}

We thank Adam Corner and Mike Beck for their help and advice. This work was conducted as part of the Postgraduate Training Partnership, co-sponsored by the Department of Trade and Industry and the Engineering and Physical Sciences Research Council.

\section{References}

BLACKETT, R. S. AND KEIM, P. 1992. Big game species identification by deoxyribonucleic acid (DNA) probes. J. Forensic Sci., 37, 590-596.

BÖHM, M., LÖW, R., HAAG-KERWER, A., LÜTTGE, U. AND RAUSCH, TH. 1993. Evaluation of comparative DNA amplification fingerprinting for rapid species identification within the genus Clusia. Bot. Acta, 106, 448-453.

DEAN, C. PICHERSKY, E. AND DUNSMUIR, P. 1989. Structure, evolution, and regulation of $\mathrm{RbcS}$ genes in higher plants. Ann. Rev. Pl. Physiol. Pl. Mol. Biol., 40, 415-439.

DOYLE, J. J. AND DOYLE, J. L. 1991. Isolation of plant DNA from fresh tissue. Biotechniques, 12, 13-15.
FERRIE, R. M., SCHWARZ, M. J., ROBERTSON, N. H., VAUDIN, S., SUPER, M., MALONE, G. AND LITTLE, S. 1992. Development, multiplexing, and application of ARMS tests for common mutations in the CFTR gene. Am. J. Hum. Genet., 51, 251-262.

FORREST, A. R. R. AND CARNIEGE, P. R. 1994. Identification of gourmet meats using FINS (Forensically Informative Nucleotide Sequencing). Biotechniques, 17, 24-26.

FUTUYMA, D. J. 1986. Evolutionary Biology, 2nd edn. Sinauer Associates, Sunderland, MA.

HAMLYN, P. F. NELSON, G. AND McCARTHY, B. J. 1992. Wool fibre identification by means of novel species specific DNA probes. J. Text. Inst., 83, 97-103.

HÖSS, M. AND PÅÅBO, s. 1993. DNA extraction from Pleistocene bones by a silica-based purification method. Nucl. Acids Res., 21, 3913-3914.

HU, J. AND QUIROS, C. F. 1991. Identification of broccoli and cauliflower cultivars with RAPD markers. Pl. Cell Rep., 10, 505-511.

JEFFREYS, A. J., WILSON, V. AND THEIN, S. L. 1985. Individual-specific 'Fingerprints' of human DNA. Nature, 316, $76-79$.

KOCHER, T. D., THOMAS, W. K., MEYER, A., EDWARDS, S. V., PAABO, S., VIllablanCA, F. X. AND WILSON, A. C. 1989. Dynamics of mitochondrial DNA evolution in animals: amplification and sequencing with conserved primers. Proc. Natl. Acad. Sci. U.S.A., 86, 6196-6200.

MANIATIS, T., FRITSCH, E. F. AND SAMBROOK, J. 1982. Molecular Cloning: a Laboratory Manual. Cold Spring Harbor Laboratory Press, Cold Spring Harbor, NY.

NELSON, G., HAMLYN, P. F. AND HOLDEN, L. 1992. A speciesspecific DNA probe for goat fiber identification. Textile Res. J., 62, 590-595.

PARRY-SMITH, D. J. AND ATTWOOD, T. K. 1991. SOMAP a novel interactive approach to multiple protein sequence alignment. $C A B I O S, 7,233-235$.

VERHEYEN, G. R., KEMPENAERS, B., ADRIAENSEN, F., VAN DEN BROECK, M., MATTHYSEN, E., VAN BROECKHOVEN, C. AND DHONDT, A. A. 1995. The genetic structure of Parus caeruleus (Blue tit) populations as revealed by minisatellite single locus probes. Heredity, 75, 571-577.

WELSH, J. AND MCCLELlAND, M. 1990. Fingerprinting genomes using PCR with arbitrary primers. Nucl. Acids Res., 18, 7213-7218.

WILLIAMS, J. G. K., KUBELIK, A. E., LEVAK, K. J., RAFALSKI, J. A. AND TINGEY, S. C. 1990. DNA polymorphisms amplified by arbitrary primers are useful as genetic markers. Nucl. Acids Res., 18, 6531-6535.

YANG, X. AND QUIROS, C. F. 1993. Identification and classification of celery cultivars with RAPD markers. Theor. Appl. Genet., 86, 205-212. 